\title{
Lake Naconiche Archaeology And Caddo Origins Issues
}

Timothy K. Perttula

Heritage Research Center, Stephen F. Austin State University

Follow this and additional works at: https://scholarworks.sfasu.edu/ita

Part of the American Material Culture Commons, Archaeological Anthropology Commons, Environmental Studies Commons, Other American Studies Commons, Other Arts and Humanities Commons, Other History of Art, Architecture, and Archaeology Commons, and the United States History Commons

Tell us how this article helped you.

This Article is brought to you for free and open access by the Center for Regional Heritage Research at SFA ScholarWorks. It has been accepted for inclusion in Index of Texas Archaeology: Open Access Gray Literature from the Lone Star State by an authorized editor of SFA ScholarWorks. For more information, please contact cdsscholarworks@sfasu.edu. 


\section{Lake Naconiche Archaeology And Caddo Origins Issues}

Creative Commons License

(c) (i) (8)

This work is licensed under a Creative Commons Attribution-NonCommercial 4.0 International License 


\title{
Lake Naconiche Archaeology And Caddo Origins Issues
}

\author{
Timothy K. Perttula
}

\section{INTRODUCTION}

Sometime around ca. A.D. 800, Lake Naconiche sites were no longer occupied by Woodland period groups of the Mossy Grove culture (Figure 1) solely making sandy paste pottery or living as mobile hunting-gathering foragers. At this time, from ca. A.D. $750-800$ to around A.D. 900 (see Perttula and Nelson 2004:Figures 4 and 5), colder and drier conditions began to dominate the local weather. After ca. A.D. 800, were the aboriginal groups Caddo peoples or acculturated Mossy Grove folks? Some findings from the Lake Naconiche (Figure 2) archaeological investigations at the Boyette site (41NA285) are relevant to this issue of ethnic affiliations and local, but nevertheless regional momentous, cultural changes.

Putting that in context, as best as can be discerned in the archaeological records of the Woodland period occupations at the Naconiche Creek (41NA236) and Boyette sites (Perttula 2008:646$650,663-668,674-680)$, if there is any evidence of increasing sedentism, it is only apparent after ca. A.D. 400 or perhaps even as late as ca. A.D. 650 , during the latter part of the period. Even so, these occupations were not sedentary in the sense of them being year-round occupations (as with the Caddo settlement history at Lake Naconiche) or even multiseasonal occupations. The sites do not have accumulations of midden deposits, there is no evidence for the construction of sturdy wood structures, and there are only a very modest assortment of burned rock, pit, or post hole features at the Woodland period sites. It is hard to disagree with Story's $(1995: 237)$ characterization of Woodland period settlements in the general area that they reflect "intermittent encampments by a relatively small group or groups over a considerable period of time."

Woodland period sites are widely distributed on many different kinds of landforms, implying the generalized use of a wide variety of habitats for settlements as well as foraging pursuits. Without a more fine-grained Woodland period chronology for Mossy Grove culture sites in East Texas, which we are a long way from achieving, it is not possible to evaluate suggestions by Corbin (1998) that there were subtle shifts on the landscape of peoples that may have been a response to changes in subsistence (i.e., the possible growing of cultivated plants). The absence of cultigens other than squash from Woodland contexts in the Lake Naconiche paleobotanical record (see Dering 2008) casts some doubt on the assertion that horticultural economies were developed during this time locally, although the number of flotation and fine-screen samples from pre-A.D. 800 contexts is still miniscule. Thus, the virtual absence of cultigens from Woodland times does not yet constitute a robust evaluation of Corbin's suggestion.

The development of sedentary life along Naconiche Creek appears to have taken place after ca. A.D. 800 by successful hunter-gatherer foragers and pottery makers, specifically amongst the earliest Caddo residents of the valley. Neither the adoption of pottery or the adoption of horticultural subsistence strategies (i.e., the cultivation of maize) appear to have been triggering events that led to the ability of these people to maintain multi-seasonal residences in the same places.

\section{THE CASE OF THE BOYETTE SITE}

The Boyette site has archaeological deposits that are relevant to the discussion of Caddo origins. Our work here consisted of extensive block excavations (Block I and II) on an upland ridge toe slope, and small alluvial terrace above Telesco Creek (Figure 3a-b); the site covers ca. 1.2 acres (Perttula 2008:181-209).

The relevant characteristics are as follows: first, there are radiocarbon-dated features and 


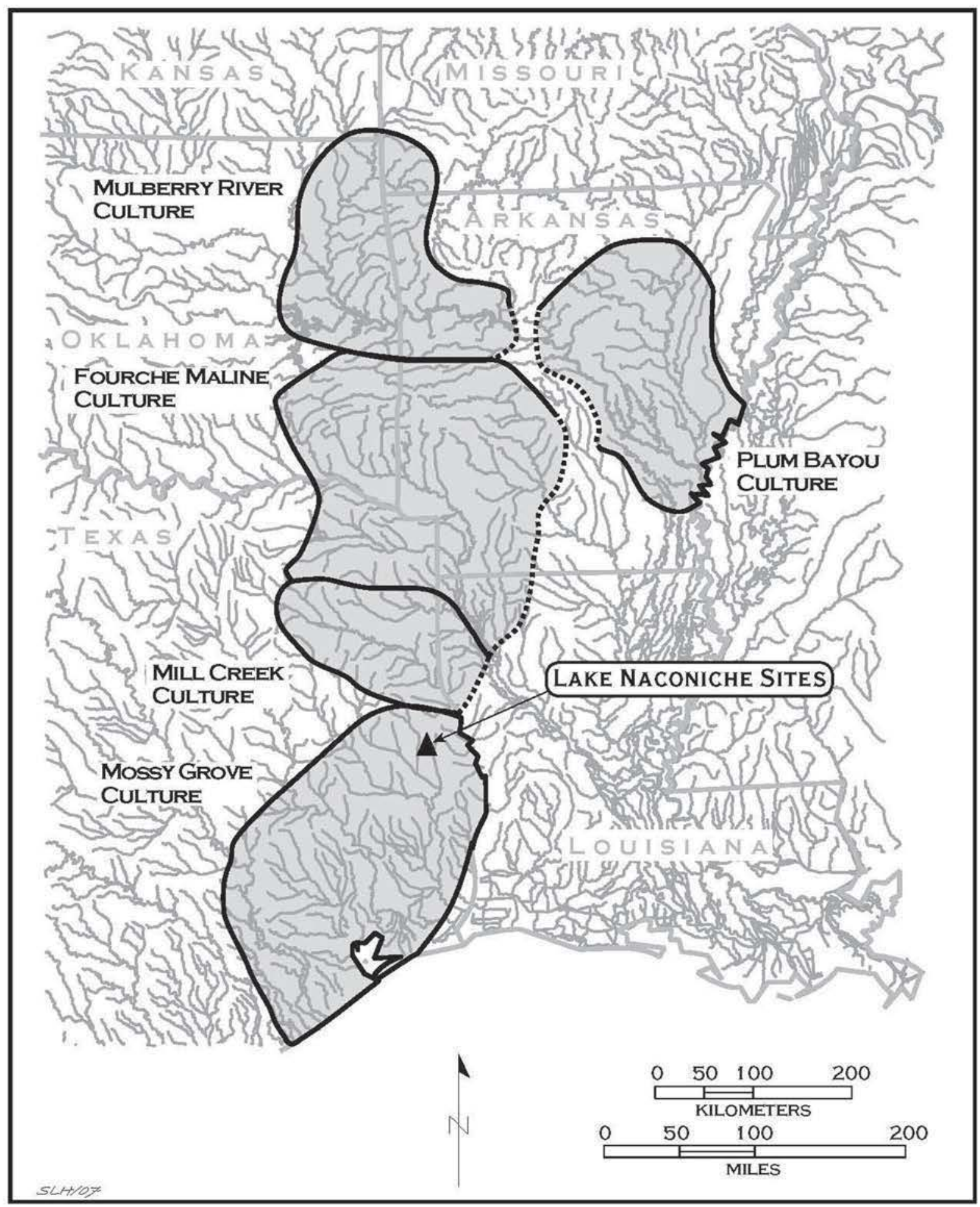

Figure 1. Woodland period cultures in the Caddo archaeological area. 


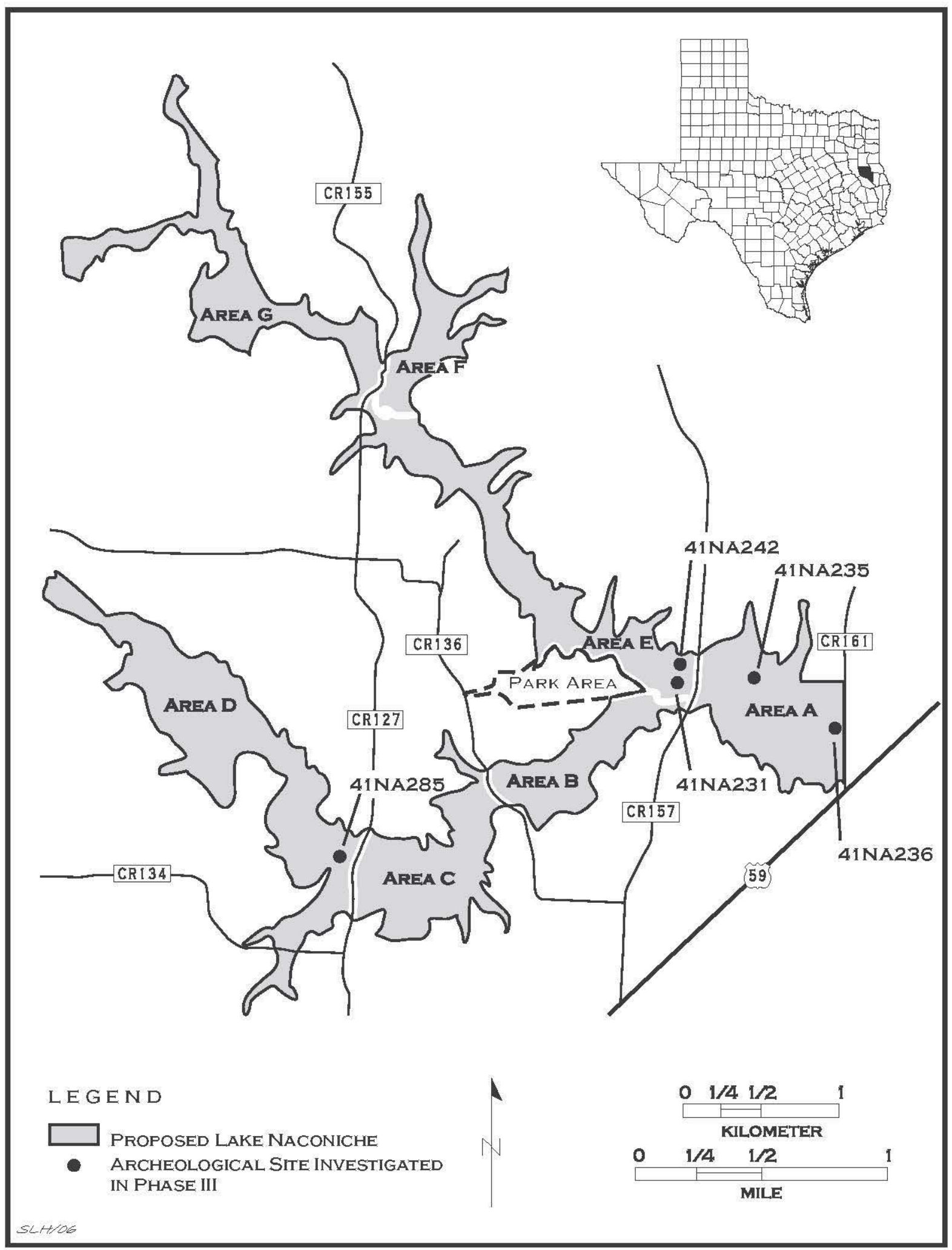

Figure 2. Lake Naconiche project area and the five sites that received data recovery investigations. 


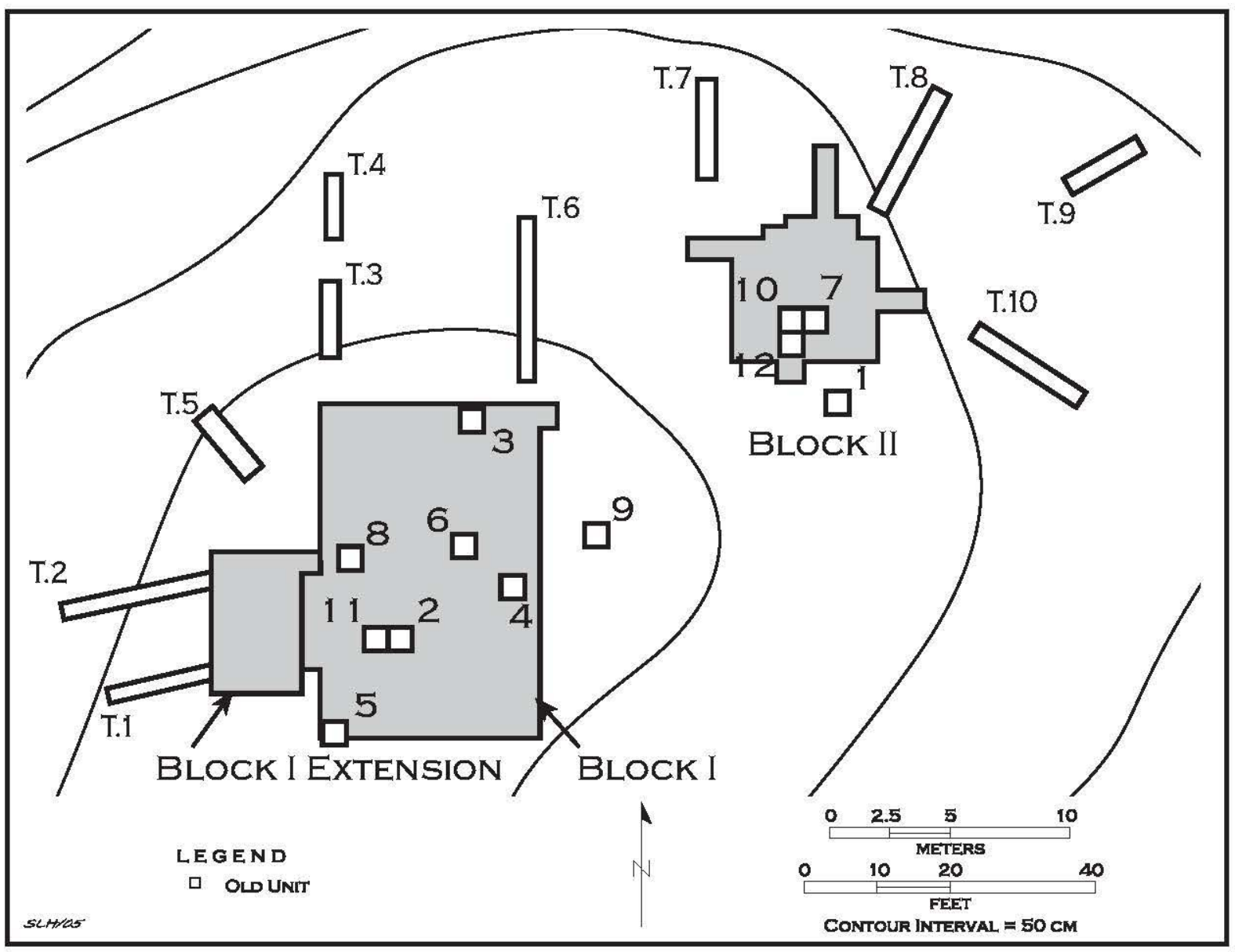

Figure 3a. The Boyette site: map of the excavations.

archaeological materials at the site that fall in the general temporal interval of interest, ca. A.D. 800850 - as well as immediately before and after that time - when the Caddo cultural tradition is generally acknowledged to become recognizable in the archaeological record in East Texas (cf. Story 2000). Second, there are relatively discrete Late Woodland (ca. A.D. 400-800) (or late Mossy Grove) and Early Caddo (ca. A.D. 800-1000) archaeological deposits at the site, and these contain some features and an extensive ceramic material culture record. Finally, the character of the ceramics from both components suggest continuities in some aspects of ceramic style and technology from the Late Woodland to the Early Caddo occupation, providing hints of from whence at least some East Texas Caddo groups may have originated.

\section{Radiocarbon dates}

Seven calibrated radiocarbon dates are pertinent, three from Late Woodland features in the northern part of Block I, and four dates from Early Caddo deposits and features in Block II (Table 1; see Perttula 2008: Table 4-26); there is also an older Woodland period date from deep in Block II. Both blocks have reasonably stratified Woodland and Early Caddo archaeological deposits. In Block II, Fea. 3 and Fea. 36 are stratified hearths associated with structural remains and post holes.

The Woodland period dates from Block I are from the lower archaeological deposits; the Early Caddo remains above them are undated. The Early Caddo period dates from Block II are from the upper archaeological deposits there; with the exception of the one date from Fea. 42, the Woodland period deposits are undated here. The decorated sandy paste ceramics, mostly of Late Woodland age, and the tempered Caddo decorated ceramics, indicate that the Late Woodland and Early Caddo deposits from both blocks are very likely to be contemporaneous.

The Late Woodland component at the Boyette site has a mean 2 sigma calibrated age range of $\mathrm{AD}$ $667-847$, with a mean calibrated intercept of $\mathrm{AD}$ 


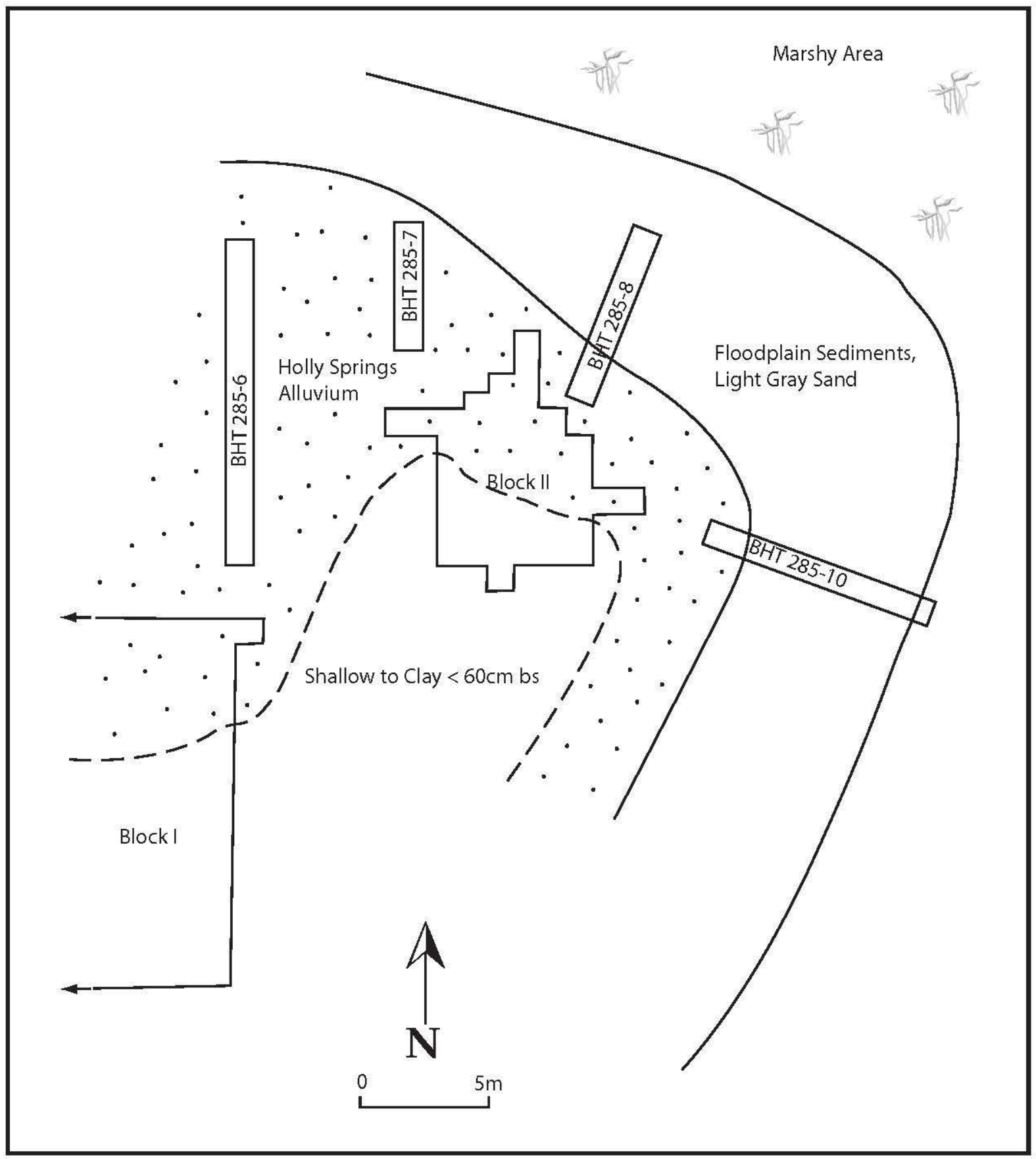

Figure 3b. The Boyette site: sediments across the site.

743. The mean 2 sigma calibrated age range of the Early Caddo occupation is AD 873-1075, with a mean calibrated intercept of AD 960. Temporal differences between the four Early Caddo dates suggest that there may be have been two occupations during the period at Boyette (although such cannot be recognized in the archaeological deposits): one with a mean age range at 2 sigma of $\mathrm{AD} 750-990$ (mean calibrated intercept of AD 890) (see Table 1), and the other with a mean age range of AD 995-1160 at 2 sigma and a mean calibrated intercept of AD 1030 (see Table 1).

\section{Late Woodland sandy paste sherds}

Sandy paste plain sherds (Goose Creek Plain, var. unspecified) are abundant at the Boyette site, Block I excavations, especially in the lower 
Table 1. Radiocarbon dates from the Boyette site.

\begin{tabular}{llll}
\hline Block & Context & 2 sigma cal. & cal. intercept \\
\hline $\begin{array}{lll}\text { Woodland } \\
\text { Block I }\end{array}$ & Fea. $1 / 9,60-87 \mathrm{~cm}$ & AD 680-890 & AD 780 \\
Block I & Fea. $1 / 10,74-90 \mathrm{~cm}$ & AD 650-770 & AD 680 \\
Block I & Fea. $1 / 14,60-80 \mathrm{~cm}$ & AD 670-880 & AD 770 \\
Block II & Fea. $35,100-108 \mathrm{~cm}$ & $360-60$ BC & 190 BC \\
\hline Early Caddo & & & \\
Block II & $20-40 \mathrm{~cm}$ & AD 1010-1180 & AD 1040 \\
Block II & Fea. 3 & AD 790-1000 & AD 900 \\
Block II & Fea. 36 & AD 710-980 & AD 880 \\
Block II & Fea. 42 & AD 980-1140 & AD 1020 \\
\hline
\end{tabular}

archeological deposits $(50-100 \mathrm{~cm} \mathrm{bs})$ and in Feature $1 / 10$ (Table 2) at the northern end of the block. The distribution of plain sandy paste sherds in the upper $50 \mathrm{~cm}$ bs appears to be predominantly a product of the contemporaneous use of sandy paste wares and grog-tempered pottery wares by Early Caddo groups living at the site (see below), while those from lower depths (where decorated sandy paste sherds are not especially common relative to the proportions seen in the overlying Caddo occupation) are considered primarily to be from a substantial Late Woodland period occupation.

The plain sandy paste rim sherds from Block I are almost always from direct or vertical walled vessels $(92 \%)$. There are a few rims with inverted $(4 \%)$ or everted (4\%) rim profiles. About $71 \%$ have rounded lips, $21 \%$ have flat lips, and two others are beveled (either towards the interior or exterior vessel wall surface). Another has a rounded, but exterior folded lip-commonly seen in Caddo pottery

Table 2. Plain sandy paste sherds from the Boyette site, Block I.

\begin{tabular}{|c|c|c|c|c|c|}
\hline Level & Rim & Body & Base & $\mathrm{N}$ & $\% \mathrm{SP} *$ \\
\hline \multicolumn{6}{|c|}{ Upper component } \\
\hline 1 & 8 & 89 & 5 & 102 & 20.9 \\
\hline 2 & 3 & 129 & 7 & 139 & 25.0 \\
\hline 3 & 8 & 118 & 6 & 132 & 21.3 \\
\hline 4 & 9 & 134 & 8 & 151 & 31.3 \\
\hline 5 & 5 & 62 & 3 & 70 & 22.5 \\
\hline \multicolumn{6}{|c|}{ Lower component } \\
\hline 6 & 7 & 80 & 4 & 91 & 46.2 \\
\hline 7 & 5 & 66 & 4 & 75 & 65.0 \\
\hline 8 & - & 20 & 2 & 22 & 55.0 \\
\hline 9 & 2 & 30 & - & 32 & 70.0 \\
\hline 10 & - & 11 & - & 11 & 85.0 \\
\hline Features & 2 & 22 & - & 24 & \\
\hline Totals & 49 & 761 & 39 & 849 & 29.1 \\
\hline
\end{tabular}

*proportion of plain sandy paste sherds among all plain sherds (both tempered and non-tempered) 
vessels from the site - and another has a rounded but pointed lip.

Vessels range from $11-34 \mathrm{~cm}$ in orifice diameter. The mean orifice diameter of these vessels - most likely cooking jars and bowls-is $18.4 \pm 4.6 \mathrm{~cm}$, generally medium-sized on average. The plain sandy paste pottery vessels from the Boyette site have relatively thin walls and a rounded, thick base. Rim walls on average range from $6.75-7.16 \mathrm{~mm}$; vessel walls are on average $6.92-7.18 \mathrm{~mm}$ in thickness, indicating the manufacture of smoothed and uniform vessel wall contours of medium thickness, well-suited to cooking use. Base sherds of sandy paste pottery range from $10-10.87 \mathrm{~mm}$ in thickness at the site, with the thickest bases among the plain sandy paste sherds from the Early Caddo component in Block I. About $16-18 \%$ of the vessel sherds have been smoothed or floated on interior and/or exterior vessel surfaces. The smoothing was done before the vessel was fired, and while the clay paste was malleable.

There is not much difference between Woodland and Early Caddo components in how the sandy paste pottery vessels were fired by aboriginal potters at the Boyette site (Table 3), indicating a technological continuity. Between $59.4-66.7 \%$ of the sherds are from vessels fired in a reducing environment, although in the earlier component more vessels were apparently left to cool in the fire rather than pulled from it to be cooled in the open air. Firing in an oxidizing or incompletely oxidizing environment was not the preferred firing method during either archaeological component.

Sherds that are from vessels that were smothered, sooted, or possibly reheated comprise between $11-14.0 \%$ in the two components. The relative frequency of these firing conditions in vessel sherds is comparable to that documented from the plain sandy paste sherds in Block II at Boyette.

There are 245 plain sandy paste sherds from Block II at the Boyette site (Table 4), including 23 plain rims and four base sherds, all from rounded base vessels. The highest proportions of sandy paste sherds occur below $50 \mathrm{~cm}$ bs.

The rim sherds (both plain and decorated) have direct $(91 \%)$, inverted $(4.5 \%)$, and everted $(4.5 \%)$ rim profiles. One has a beveled lip, $50 \%$ have a rounded lip, another $42 \%$ have flat lips, and one other has a pointed lip. The mean orifice diameter of the sandy paste vessels from Block II at the Boyette site is $19.0 \pm 3.63 \mathrm{~mm}$, with a range of $13-29 \mathrm{~cm}$. Medium to large-sized vessels were used in Woodland period times at the Boyette site. About $55 \%$ of the vessel sherds have been smoothed on interior and/or exterior surfaces, smoothing occurring a bit more commonly on the vessel exterior $(57 \%)$ compared to the vessel interior (54\%). Less than $1 \%$ have been burnished, and $2 \%$ have remnants of organic residues preserved on them.

The majority of the plain sandy paste sherds from Block II are from vessels fired in a reducing environment, regardless of depth (62.7-70\%); most of these were subsequently cooled in an open or oxidizing environment (Table 5). Incompletely oxidized vessel sherds are notably more abundant in the $0-50 \mathrm{~cm}$ component, while sherds from thoroughly oxidized vessels are more abundant in the probable Woodland period deposits below $50 \mathrm{~cm}$ bs (Table 5 ). The distinctive smudged, sooted, or reheated vessel sherds account for $12.5-15 \%$ of all the vessel sherds from the various block contexts, comparable to the sandy paste vessel sherds from the Block I sandy paste sherds from the Boyette site, and the tempered wares from the deepest archaeological deposits in Block II.

Table 3. Firing conditions of plain sandy paste sherds, Block I at the Boyette site.

\begin{tabular}{lccc}
\hline Firing Conditions & $0-50 \mathrm{~cm}$ & $50-100 \mathrm{~cm}$ & Features \\
\hline Oxidizing & $12.5^{*}$ & 8.3 & 4.3 \\
Incompletely Oxidized & 16.1 & 11.1 & 4.3 \\
Reducing & 23.0 & 35.2 & 26.1 \\
Reducing, cooled in open air & 36.4 & 31.5 & 56.5 \\
Smothered, sooted, reheated & 11.0 & 14.0 & 4.3 \\
\hline Totals & 256 & 108 & 23 \\
\hline
\end{tabular}

*percent 
Table 4. Plain sandy paste sherds from the Boyette site, Block II.

\begin{tabular}{lccccc}
\hline Level & Rim & Body & Base & N & $\%$ SP* \\
\hline Upper component & - & 18 & - & 18 & 51.4 \\
1 & 1 & 19 & - & 20 & 37.0 \\
2 & 1 & 23 & - & 24 & 51.1 \\
3 & 4 & 25 & - & 29 & 54.7 \\
4 & 1 & 28 & 1 & 30 & 61.2 \\
5 & 1 & & & & \\
\hline Lower component & 7 & 28 & - & 29 & 61.7 \\
6 & 6 & 29 & - & 32 & 84.2 \\
7 & 1 & 12 & - & 14 & 64.8 \\
8 & - & - & - & - & - \\
9 & 1 & 2 & - & 3 & 100.0 \\
10 & - & 3 & 4 & 3 & 100.0 \\
11 & & & & 245 & 56.5 \\
\hline
\end{tabular}

*proportion of plain and decorated sandy paste sherds among all sherds (tempered and non-tempered)

Table 5. Firing conditions of plain sandy paste sherds, Block II at the Boyette site.

\begin{tabular}{lccc}
\hline Firing Conditions & $0-50 \mathrm{~cm}$ & $50-120 \mathrm{~cm}$ & Features \\
\hline Oxidizing & $3.9^{*}$ & 11.7 & 12.5 \\
Incompletely oxidized & 19.6 & 5.0 & - \\
Reducing & 25.5 & 30.0 & 37.5 \\
Reducing, cooled in open air & 37.2 & 40.0 & 25.0 \\
Smothered, sooted, reheated & 13.8 & 15.0 & 12.5 \\
\hline Totals & 51 & 60 & 8 \\
\hline
\end{tabular}

*percentage

There are also decorated sandy paste sherds found in the deeper archaeological deposits in Block I and Block II at the Boyette site (Table 6). In Block I, $8.3 \%$ of the sandy paste sherds are decorated in this earlier Woodland archaeological component, compared to $11.9 \%$ decorated among the overlying Early Caddo component sandy paste sherds.

The decorated sherds from the lower archaeological deposits in Block I include incised (56.5\%), punctated $(17.4 \%)$, incised-punctated $(21.7 \%)$, and rocker stamped sherds (4.3\%). The absence of lip notched rim sherds is telling with respect to the likely age of the Woodland period occupation in Block I, in that lip notched rims appear to be more abundant in pre-A.D. 300 contexts at Lake Naconiche (Perttula 2008:433).

Incised sandy paste vessel sherds are more common in the lower Block I archaeological deposits, while incised-punctated vessel sherds are more common in the upper Caddo component (see Perttula 2008:Table 7-4). The incised sherds are primarily from vessels decorated with a series of parallel- 
Table 6. Decorated sandy paste sherds from the lower Woodland component at the Boyette site, Block I.

Decorative Element

Incised

parallel incised-V-shaped line

parallel incised, broad line

broad opposed incised lines

diagonal incised

broad curvilinear incised line

horizontal and diagonal incised

Subtotal

\section{Punctated}

small circular punctated rows

curvilinear circular punctated rows

tool punctated rows

Subtotal

\section{Incised-Punctated}

straight incised line-circular punctated row

broad incised line-triangular zone filled with

large circular punctations

incised line-circular punctated zone

horizontal, circular, and panel incised zones

filled with tool punctates

broad incised line and tool punctations

Subtotal

Rocker stamped

No, of sherds

7

1

2

1

1

1

13

1

1

2

4

1

1

1

1

1

5

1

Totals

23

probably horizontal-lines, although opposed, curvilinear, diagonal, and horizontal-diagonal elements are also present (Figure 4). This is not much different than the incised sandy paste sherds in the overlying Caddo component.

Punctated sandy paste sherds include circular as well as tool punctated elements. These punctations are arranged in either straight or curvilinear rows (see Figure 4). The predominance of circular punctations is also characteristic of the punctated sandy paste sherds from the overlying Caddo component.

The incised-punctated sherds have either circular/semi-circular, triangular, or paneled incised zones filled with tool punctations or large circular punctations (see Figure 4). Sixty percent of the incised-punctated sandy paste sherds from this component have circular punctations, compared to $40 \%$ of the incised-punctated sandy paste sherds in the later Caddo component in Block I. Circular zones filled with punctations are common in the small sample from the Woodland deposits in Block I, but not in the overlying prehistoric Caddo component. The incised lines are a mix of narrow V-shaped and broad, shallow lines.

The one rocker stamped body sherd in Block I has a single row of rocker stamps, obviously part of a larger decorative element probably consisting of curvilinear incised zones filled with rocker stamping. This particular rocker stamped pottery may be an example of Marksville Stamped, var. Troyville 


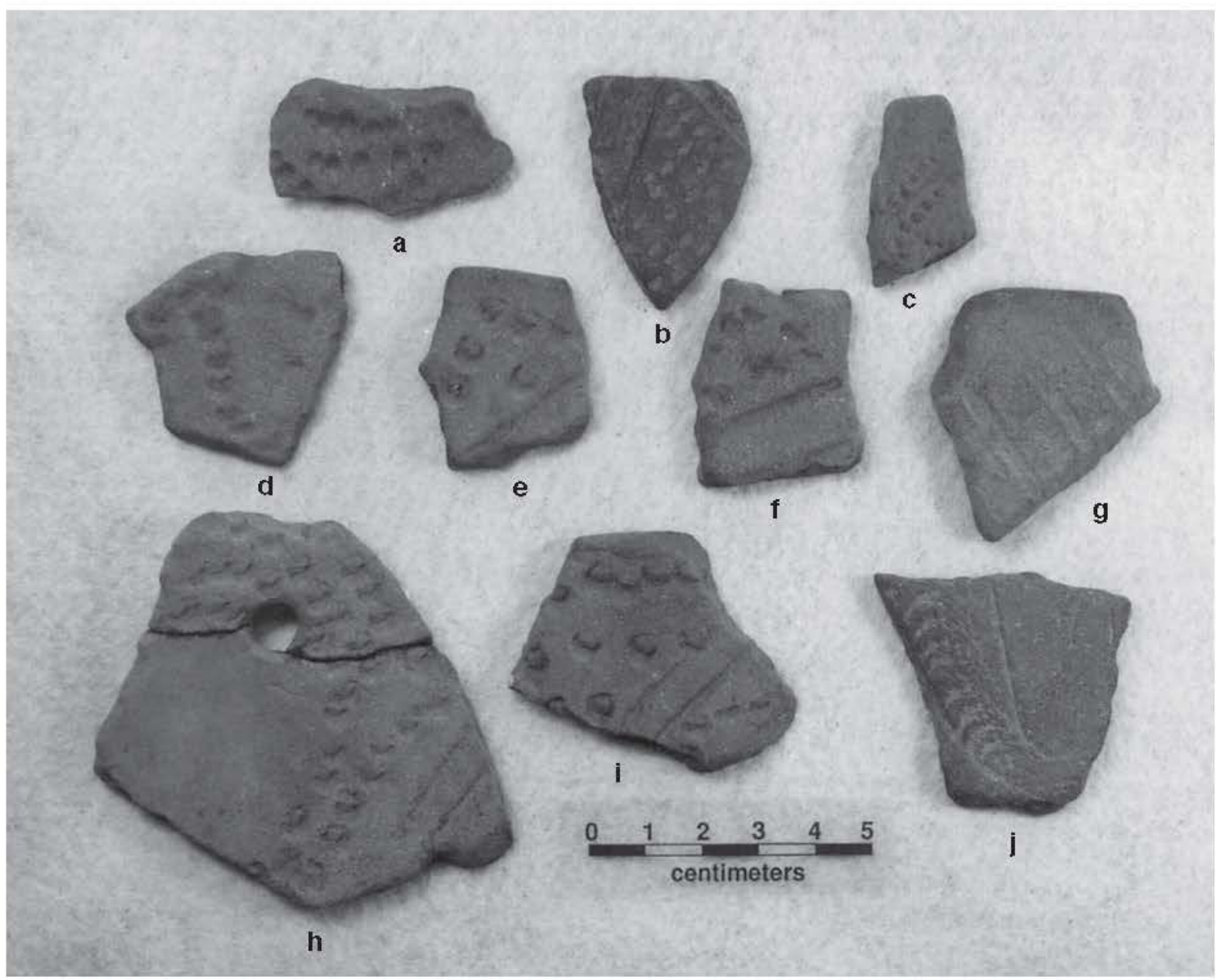

Figure 4. Sandy paste decorated sherds from Block I: a-c, e-f, h-i, incised-punctated; d, punctated; g, incised; j, incised and rocker stamped.

(see Brown 1998), dated from ca. A.D. 100-300 in the lower Mississippi valley; Girard (2008 personal communication) suggests that Troyville pottery may date as late as the period of ca. A.D. $400-700$ in the lower Mississippi valley, and thus the occurrence of this sherd at the Boyette site would not be out of place in a late Mossy Grove context.

The Block II decorated sandy paste sherds $(\mathrm{n}=16)$ at Boyette include incised $(43.8 \%)$, incisedpunctated $(37.5 \%)$, lip notched $(12.5 \%)$, and incised-rocker stamped ( $6.3 \%)$. The decorated sherds comprise only $6.1 \%$ of all the sandy paste sherds from the Block II excavations at Boyette.

The incised sandy paste Woodland sherds have straight-line elements. This includes single straight broad lines $(n=1)$, single straight $\mathrm{V}$-shaped lines $(\mathrm{n}=3)$, rim sherds with broad but shallow horizontal and vertical incised lines ( $\mathrm{n}=2$ ), and broad straight and diagonal incised lines $(\mathrm{n}=1)$.
Among the incised-punctated sandy paste sherds from Block II, the designs consist of straight incised lines forming triangular zones filled with punctations of various sorts. Punctations used as filler include tool $(\mathrm{n}=3)$ and circular $(\mathrm{n}=2)$ punctations. One body sherd - from a sandy paste carinated bowl-has straight incised lines with one row of circular punctations alternating with a row of tool punctations.

The one incised-rocker stamped sherd (40-50 $\mathrm{cm}$ bs, probably Marksville Stamped, var. Troyville) has a broad and shallow incised line, probably part of a curvilinear zone filled with rocker stamping. The lip notched rims (both from below $50 \mathrm{~cm} \mathrm{bs}$ ) have shallow opposed notches along the lip.

\section{Early Caddo sandy paste sherds}

There are 103 decorated sandy paste sherds recovered from the Block I excavations at the 
Table 7. Decorated sandy paste sherds from the upper Early Caddo component at the Boyette site.

Decorative Element

Incised

single straight incised line

single broad incised line

parallel incised-V-shaped line

parallel incised, broad line

cross-hatched incised

opposed incised lines

diagonal incised

single curvilinear incised line

broad straight and curvilinear incised

horizontal incised, V-shaped lines

horizontal and diagonal incised

deep zigzag incised lines*

Subtotal

No.

\section{Punctated}

small circular punctated rows

3

large circular punctated rows $\quad 4$

circular punctated panel $\quad 1$

tool punctated rows 4

cane punctated rows 1

$\begin{array}{ll}\text { Subtotal } & 13\end{array}$

\section{Incised-Punctated}

straight incised line-large circular punctations $\quad 2$

straight incised line and small circular punctations 3

single broad incised line with large circular punctations $\quad 1$

broad incised line-triangular zone filled with large circular punctations $\quad 1$

broad incised line-circular zone filled with circular punctations $\quad 1$

$\begin{array}{ll}\text { diagonal incised-triangular zone filled with large circular punctations } & 2\end{array}$

broad diagonal incised-triangular zone filled with tool punctations 3

$\begin{array}{ll}\text { opposed incised-triangular zone filled with tool punctations } & 1\end{array}$

opposed incised-triangular zone filled with large circular punctations $\quad 1$

broad parallel incised with curvilinear rows of circular punctations 1

horizontal and circular incised with circular zone of tool punctates 1

broad parallel incised with circular tool punctated zone 1

broad incised line and triangular zone filled with tool punctations 1

broad incised line and tool punctations 1

parallel incised-large tool punctated rows 1

parallel incised-tool punctated zone 3

$\begin{array}{ll}\text { circular incised zone filled with tool punctations } & 1\end{array}$

straight incised line and circular zone filled with tool punctations 1

straight incised line and triangular zone filled with tool punctations 4

$\begin{array}{ll}\text { Subtotal } & 30\end{array}$ 
Table 7. (Continued)

Decorative Element

No.

Incised-Rocker Stamped

shallow incised-rocker stamped

shallow zoned incised-rocker stamped

broad curvilinear incised line-rocker stamped

Subtotal

1

1

4

Rocker stamped

1

Lip notched

1

Totals

80

*bottle

Boyette site. More than $75 \%$ of these distinctive sherds were found from $0-50 \mathrm{~cm}$ bs in an Early Caddo occupation; three others were found on the surface in the West Block Extension, and one came from a feature (Table 7). The proportion of decorated sandy paste sherds in the overall sandy paste sherd assemblage recovered in this component is $11.9 \%$, a good bit higher than in earlier Woodland period ceramic assemblages from Block II at Boyette or at the Naconiche Creek site (41NA236) in pre-A.D. 400 contexts. This proportion of decorated sherds among the sandy paste sherds in the upper $50 \mathrm{~cm}$ of Block I is still twice as low as is documented in the tempered Caddo wares from the site (ca. 24\%).

The sandy paste decorated sherds from the upper component at the Boyette site are primarily represented by incised $(37.5 \%)$, incised-punctated $(37.5 \%)$, and punctated (16.3\%) decorative elements. There are a few - and almost assuredly mixed or incorporated into the overlying Caddo component from the underlying Woodland period deposits-incisedrocker stamped sherds $(5 \%)$, one rocker stamped sherd $(1.3 \%)$, and one lip notched sherd (1.3\%).

The incised sherds are dominated by straight-line motifs, either parallel, horizontal, opposed, diagonal (see Figure 4g), cross-hatched in a few instance, or a combination of horizontal and diagonal lines, all probably on vessel rims and/or upper vessel bodies. The same range of incised sherd decorative elements have been documented in the tempered Caddo wares from the Boyette site, but not in the same proportions. Among the sandy paste incised sherds, there is a much lower proportion of cross-hatched decorations (although the relative frequency of cross-hatching is not much different than is documented among the tempered Caddo wares from Block II), as well as lower amounts of both horizontal and diagonal incised decorative elements in the sandy paste sherds from Block I. Most of the incised lines are narrow and V-shaped in profile, although about $17 \%$ have broad incised lines. Two incised sherds have curvilinear incised elements, roughly comparable in proportions $(6.4 \%)$ to the tempered Caddo incised sherds from Block I. One incised body sherd has deep and narrow zigzag incised lines (not duplicated among the tempered incised sherds from the Boyette site); its interior thickened body suggests this sherd is part of a sandy paste bottle.

Among the incised-punctated sandy paste sherds, there is also a wide variety of decorative elements. Most consist of straight, diagonal, or opposed incised lines (occasionally broad-lined but mostly narrow and $\mathrm{V}$-shaped) that have created triangular or circular zones filled with different sorts of punctations on vessel rims. Triangular punctatedfilled zones are most common (see Figure 4a-b), although there are circular punctated-filled zones on a few sherds; circular punctations typically filled these incised zones. Again, these characteristics of the sandy paste incised-punctated sherds from the Boyette site are basically the same seen on the tempered Caddo incised-punctated sherds, although the frequency of curvilinear-circular zonedincised-punctated sherds are much less common (6.7\% , compared to between $29-49 \%$ of all the incised-punctated tempered Caddo sherds) among these sandy paste decorated sherds. Furthermore, fingernail and linear punctated-filled zones are absent among the sandy paste incised-punctated sherds, and the frequency of tool punctated elements 
(60\% of the incised-punctated sherds have tool punctations) is considerably higher in the sandy paste sherds from Block I at the Boyette site.

One distinctive sherd (with a suspension hole) has broad and deep incised lines above two or three curvilinear rows of large circular punctations (see Figure 4h). A large suspension hole has been drilled through one of the curvilinear punctated rows. Another sherd has a single straight incised line with closely nestled small tool punctations on either side of the line; it does not appear to be part of a punctated-filled triangular incised element.

The punctated sherds include tool (see Figure $4 \mathrm{~d}$ ), cane, and circular punctated (also probably made with a tool, but the circular punctated marks are sufficiently distinctive to warrant a different categorization) elements. Most of the Block I punctated sandy paste sherds have circular punctations $(61.5 \%)$, either small or large in execution; the Caddo punctated sherds are mostly made with a tool that was triangular-shaped on its end, although circular punctated elements are characteristic of the Early ceramic set defined from the Boyette Caddo decorated sherds. The large circular punctations are deeply tool impressed-probably with a cane tool-causing a raised ridge of clay inside the punctation itself. The small circular tool punctations are pin-prick-sized (preserving the impression of the small tool head) and usually occur in narrow rows; these latter punctations have no counterpart in the tempered Caddo punctated sherds. Another notable difference between the sandy paste punctated sherds and the tempered punctated sherds is the absence of both fingernail or linear punctations among the former.

In summary, while incised, punctated, and incised-punctated decorative elements are present in both the sandy paste sherds (from $0-50 \mathrm{~cm} \mathrm{bs}$ ) and the tempered Caddo sherds from the Block I ceramic assemblage at the Boyette site (see Table 7), the two different assemblages do not have the same proportion of specific elements or motifs. Although sample size differences may play a role in the fact that there are considerable proportional differences between the two assemblages - or they may be in fact stylistically different (and hence temporally different?) - nevertheless the same decorative decisions were made by the potters that decorated the two wares. That is, among the incised sherds, simple straight and geometric designs were preferred; the punctated sherds were decorated most commonly with straight rows of punctations executed with a tool; and incised-punctated sherds usually had triangular incised zones filled with punctations. Usually, the incised zoned were filled with triangular punctations. This suggests that both wares were made during the Early Caddo occupation in Block I at Boyette.

Among the decorated sandy paste sherds from the Boyette site are a few larger sherds where vessel forms could be determined. Most appear to be from straight-walled vessels - probably jars and bowls with rounded bases - but there is at least one bottle sherd and several sherds from carinated bowls (one with rows of small circular punctations and another with opposed incised lines). The same kinds of vessel forms were noted in the tempered Caddo decorated wares.

\section{Early Caddo tempered ceramics}

The Early Caddo ceramics at Lake Naconiche are distinguished by engraved fine wares (Figure 5ab) and incised, punctated, and incised-punctated utility wares. Among the rims from bowls and carinated bowls, Holly Fine Engraved is only present in Block II at the Boyette site (Table 8), and is certainly the most distinctive engraved ware in the Early Caddo ceramic set. Also in Block II, other common rims have sets of horizontal lines, diagonal lines, vertical and horizontal lines, or broadly excised horizontal and vertical engraved lines. These latter rims are from a vessel with a non-tempered sandy paste, suggesting there is a temporal relationship between this early engraved element and the continued use of sandy paste pottery, which is otherwise being made and used for plain or simple decorated vessels in East Texas up until the $9^{\text {th }}$ century A.D. or later.

Early set engraved rims from Block I include a wide variety of decorative elements, primarily geometric designs (i.e., diagonals and opposed lines) as well as sets of horizontal lines (see Table 8), but geometric and horizontal engraved decorations are characteristic of Lake Naconiche engraved wares from the earliest to the latest prehistoric Caddo ceramics. More distinctive engraved rim elements include cross-hatching and hatched zones (oriented in diagonal, curvilinear, and vertical directions on the rim), as well as cross-hatched and hatched pendant triangles and a circle and cross (Figure 6). Although the low number of engraved rims from Block II precludes definitive conclusions, it is interesting to note the absence of hatched engraved rims in these archeological deposits, but their relative frequency in the Block I engraved sherd assemblage (see Table 


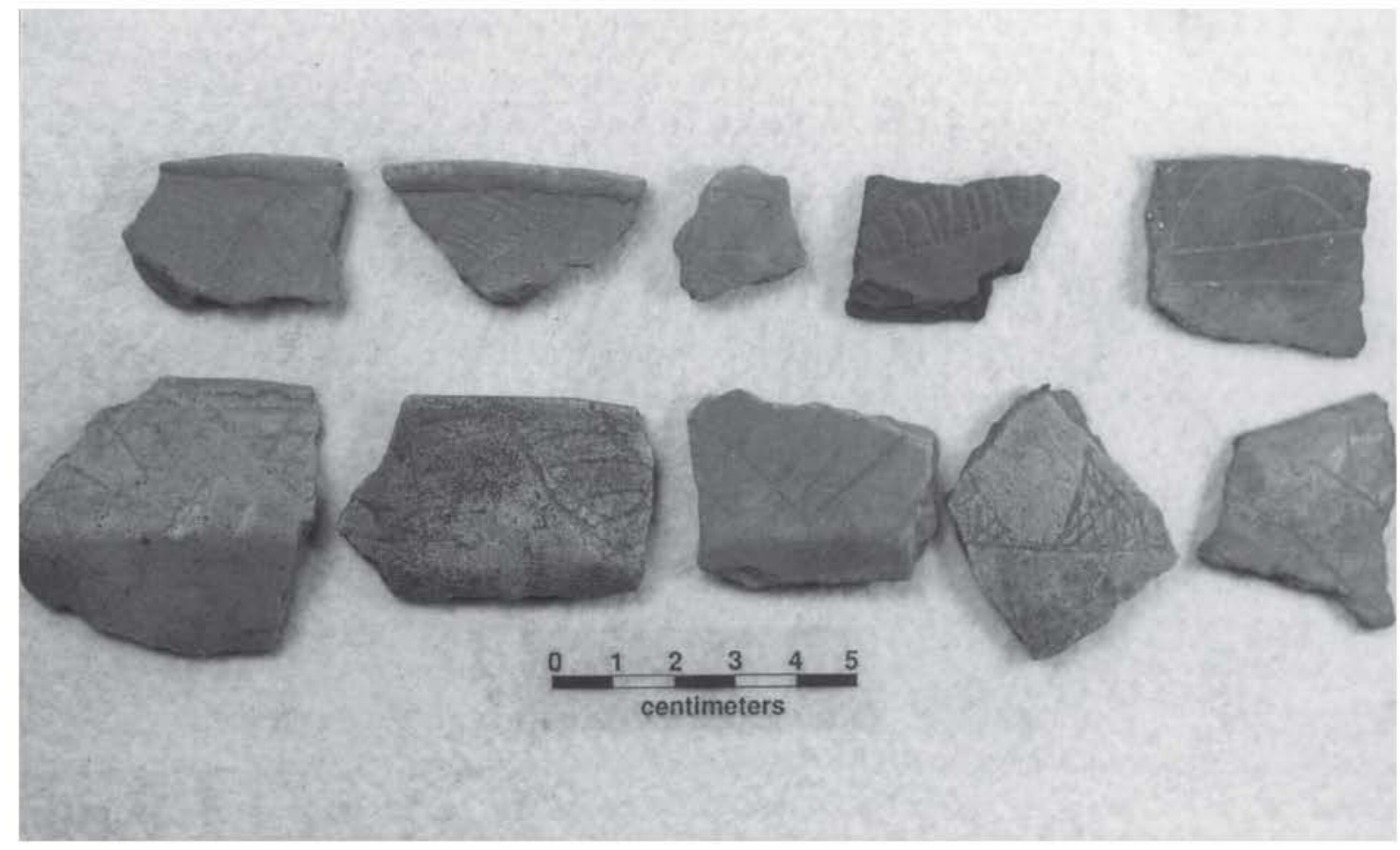

a

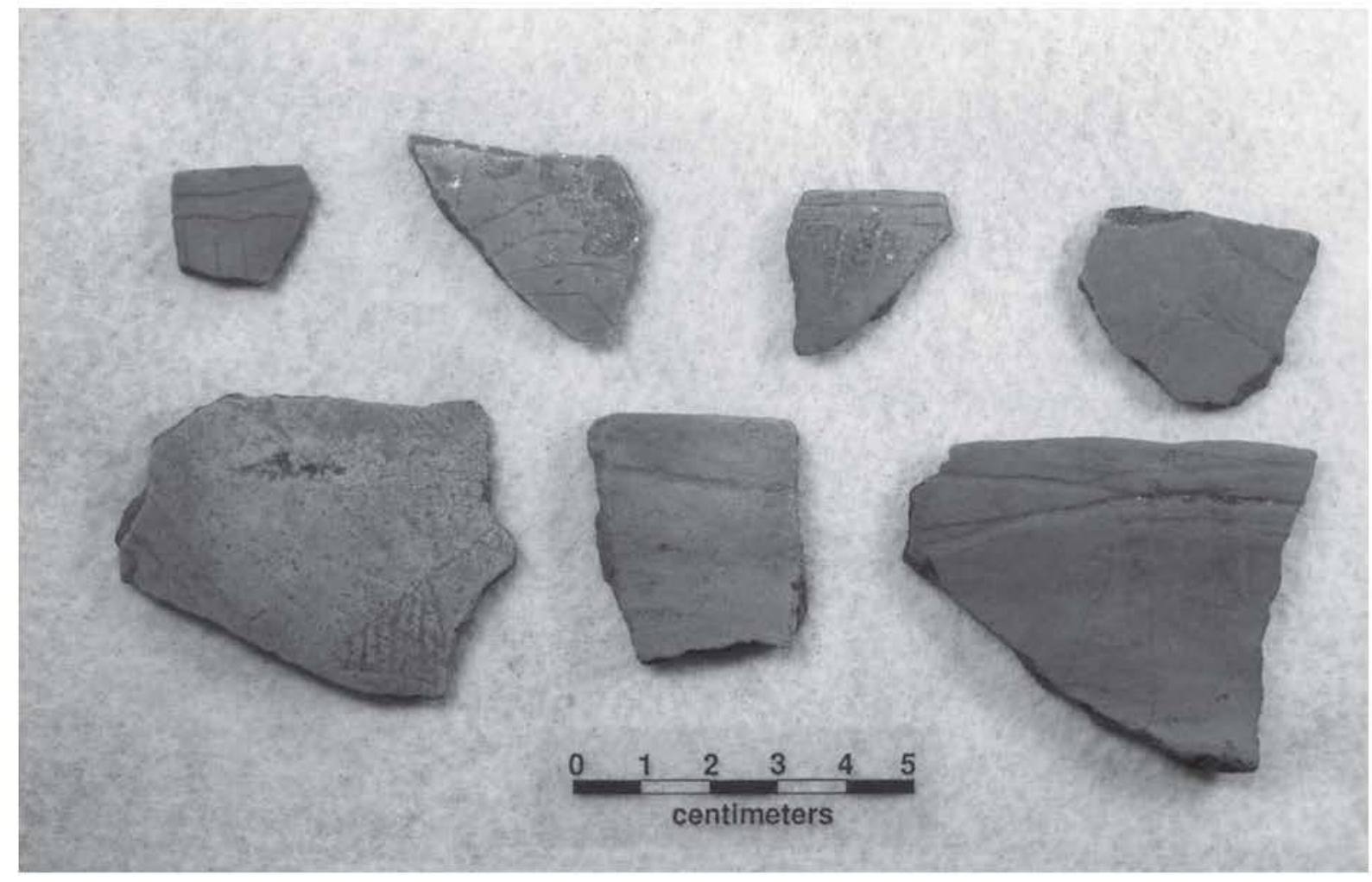

b

Figure 5. Engraved rim and body sherds from the Boyette site: a, Block I; b, Block II. 
Table 8. Engraved rim decorative elements at the Boyette site.

\begin{tabular}{lcc}
\hline Element & Block I & Block II \\
\hline cross-hatched lines & $15.0^{* *}$ & - \\
cross-hatched pendant triangle & 1.7 & - \\
circle and cross & 1.7 & - \\
hatched zones & 18.3 & - \\
Holly Fine Engraved & - & 27.3 \\
horizontal lines & 16.7 & 36.3 \\
horizontal-vertical lines & 3.3 & $18.2^{* *}$ \\
horizontal and diagonal lines & $3.3^{* *}$ & - \\
diagonal lines & 25.0 & 18.2 \\
diagonal and opposed lines & 1.7 & - \\
opposed lines & 3.3 & - \\
vertical lines & 1.7 & - \\
hatched pendant triangles & 5.0 & - \\
\hline $\mathrm{N}$ & 60 & 11 \\
\hline
\end{tabular}

*percentage; ${ }^{* *}$ both sandy paste

8). Given that hatched rims are also rather common in the Middle Caddo ceramics, their occurrence in Block I at the Boyette site suggests that the earliest Caddo occupation comprising the Early Caddo ceramic set was in Block II, followed by Block I.

One of the rims has deeply excised horizontal and diagonal lines, all enclosed within a rectangle (see Figure 61). This particular rim is from a sandy paste non-tempered vessel. A larger rim of the same vessel was recovered from Unit 3 in the test excavations at the Boyette site (Perttula 2002:Figure 4.107a).

Early Caddo engraved body sherds from Block II include hatched pendant triangles (Figure 7c, f) and Holly Fine Engraved (Table 9). Engraved body sherds in Block I are dominated by cross-hatched, hatched zones, and sherds with curvilinear elements, as well as large pendant triangles. Holly Fine Engraved sherds comprise $6 \%$ of the engraved body sherds.

In addition to these distinctive Early Caddo engraved body sherds, a goodly number also have simple straight or geometric elements, including horizontal lines, parallel lines, opposed lines, diagonal lines, and vertical lines. These body sherds comprise $28.1 \%$ of the Block I engraved body sherds (see Table 9).

The Early Caddo engraved bottle sherds from Block II at Boyette are dominated by Holly Fine Engraved sherds (Table 10). The others have simple sets of either parallel or curvilinear-horizontal lines, possibly also from Holly Fine Engraved bottles (see Suhm and Jelks 1962:Plate 40e, g).

The bottle sherds from Block I at the Boyette site, also part of the Early Caddo ceramics, primarily have sets of curvilinear engraved lines, but both Hickory Engraved and Holly Fine Engraved bottles comprise part of this distinctive engraved assemblage (see Table 10). Less common, but still apparently diagnostic of the Early Caddo ceramic set are semi-circles and panel and negative oval elements (see Table 10).

\section{Boyette site vessel}

The one vessel from a funerary context at the Boyette site is a Holly Fine Engraved globular bowl from Feature 13A in Block II (Figure 8a). The engraved decoration is confined to the rim, and consists of sets of 12 large triangular panels around the rim filled with diagonal engraved lines that are pitched in opposite and alternating directions from one triangular panel to the next (Figure 8b). Each large triangular panel has an excised triangle in one corner, alternating from the top left to the bottom left corners from one panel to another. There is a single horizontal engraved line that encircles the bottom of the rim and each of the triangular panels; rim height is $4.9 \mathrm{~cm}$. 


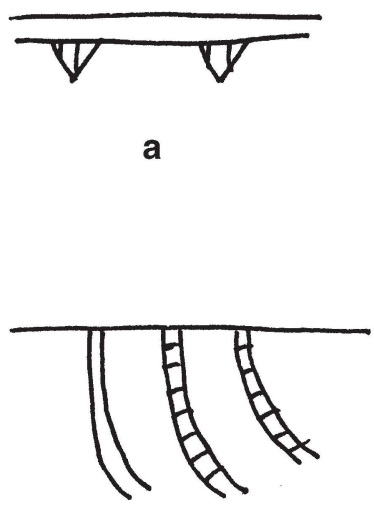

d

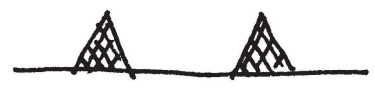

g

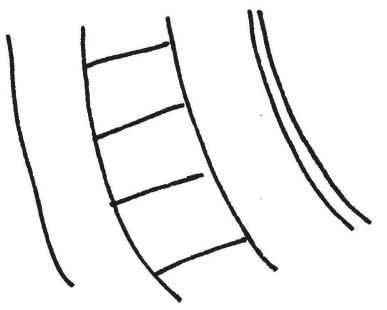

j

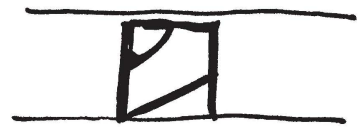

I

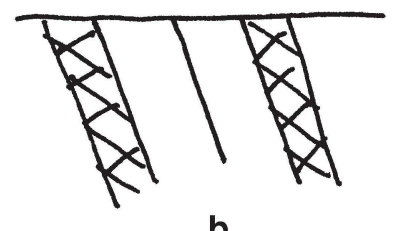

b

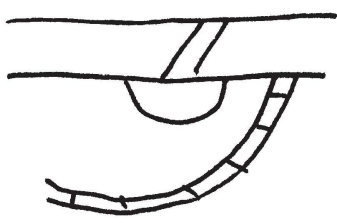

e

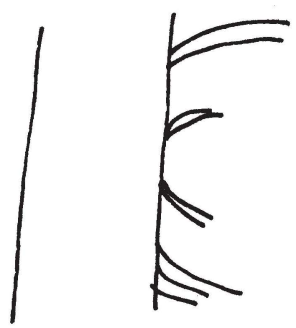

h

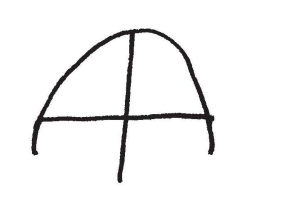

c

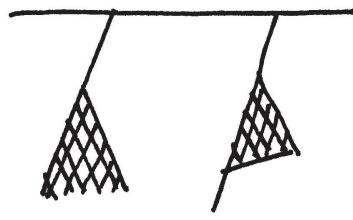

f

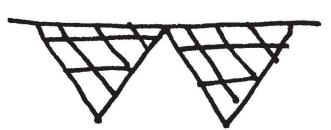

i

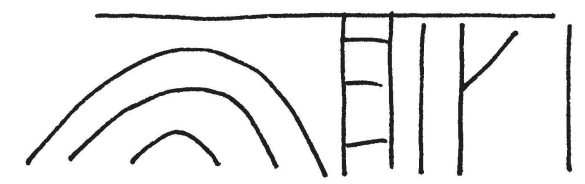

k

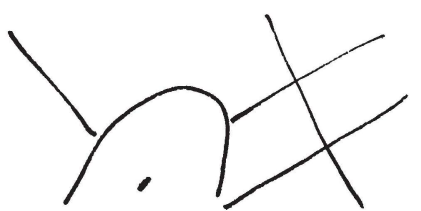

m

Figure 6. Distinctive Early Caddo engraved elements from Block I at the Boyette site.

The bowl is $14.71 \mathrm{~cm}$ in height, with a 14.68 $\mathrm{cm}$ orifice diameter. It is tempered with grog, and was fired in a reducing environment, then allowed to cool in the open air. The rim is $5.2 \mathrm{~mm}$ thick, the body is $6.2 \mathrm{~mm}$ thick, and the flat base is only $5.7 \mathrm{~mm}$ thick. The exterior vessel surface is well burnished, as is the interior rim area; the interior vessel body is poorly smoothed. There are small patches and flecks of charred organic remains on the lower exterior vessel body, and in one area along the body-base juncture on the vessel interior, as well as several fire clouds. 


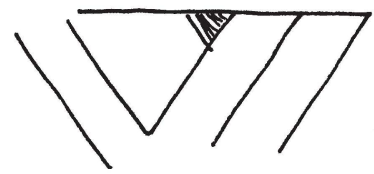

a

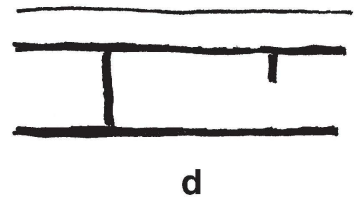

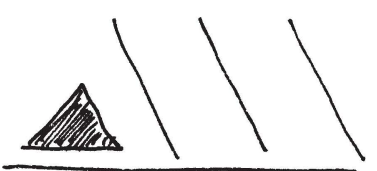

b

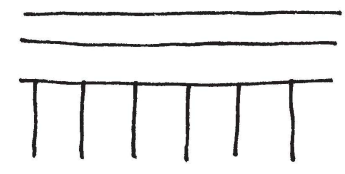

e
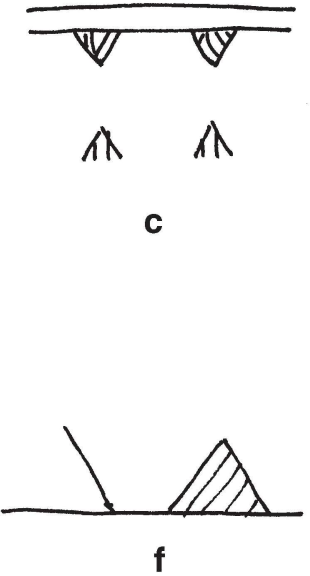

Figure 7. Distinctive engraved elements from Early Caddo sherds in Block II at the Boyette site.

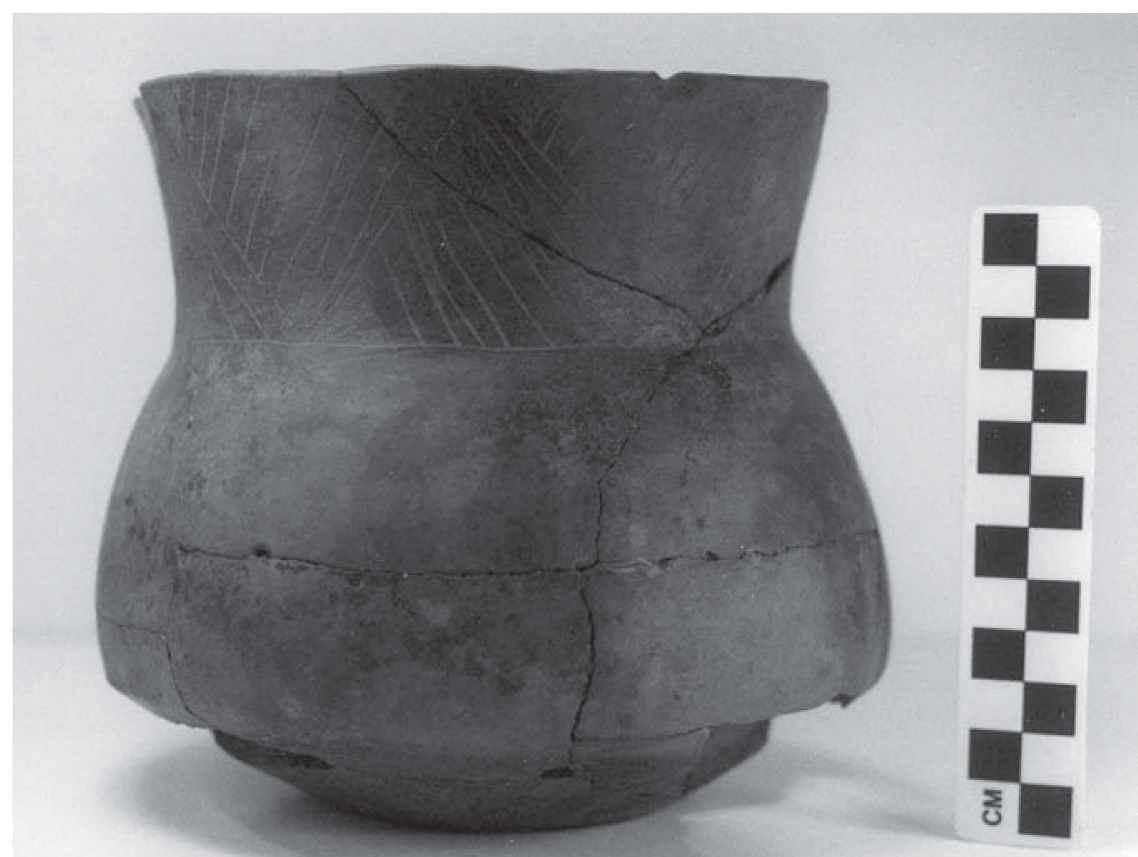

a

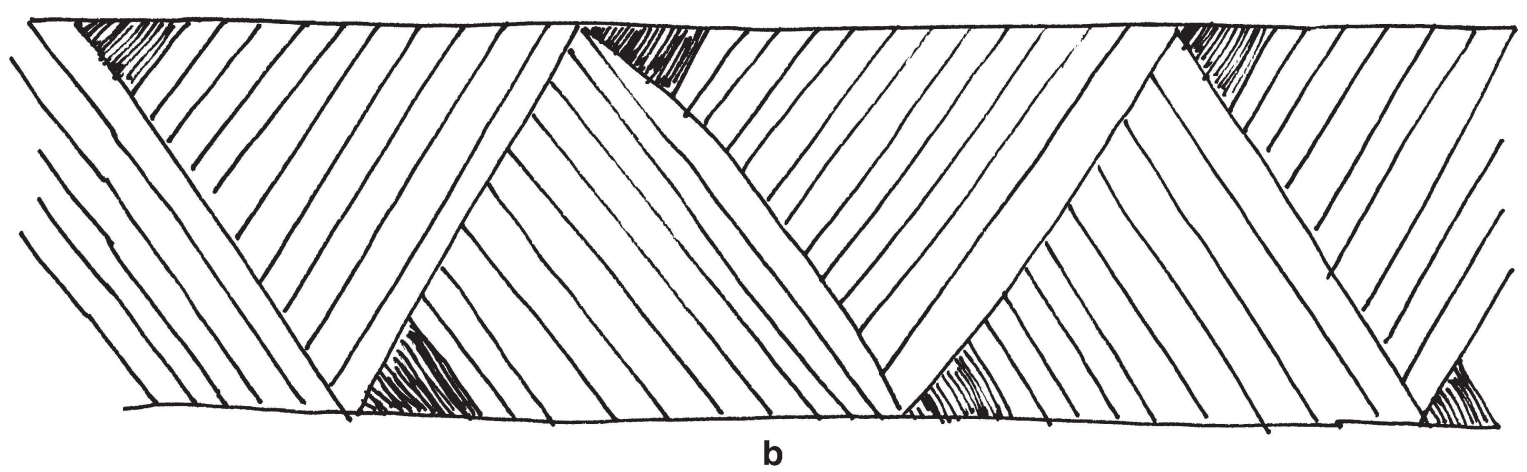

Figure 8. Holly Fine Engraved vessel from Feature 13A: a, photograph; b, drawing of the rim motif. 
Table 9. Engraved body sherd decorative elements, carinated bowls and bowls, from the Boyette site.

\begin{tabular}{|c|c|c|}
\hline Element & Block I & Block II \\
\hline large pendant triangle & $7.5^{*}$ & 50.0 \\
\hline Holly Fine Engraved & 6.0 & 25.0 \\
\hline cross-hatched lines & 19.4 & - \\
\hline cross-hatched zone & 3.0 & - \\
\hline horizontal & 2.2 & - \\
\hline horizontal and diagonal lines & 2.2 & - \\
\hline horizontal-vertical-zigzag & 0.7 & - \\
\hline horizontal and cross-hatched lines & 3.7 & - \\
\hline horizontal and opposed lines & 0.7 & - \\
\hline parallel lines & 8.2 & - \\
\hline opposed lines & 6.7 & - \\
\hline diagonal lines & 3.0 & - \\
\hline vertical lines & $0.7 * *$ & - \\
\hline hatched zones & 13.4 & - \\
\hline hatched zones and opposed lines & 0.7 & - \\
\hline \multicolumn{3}{|l|}{ hatched zones and curvilinear } \\
\hline lines & 3.0 & - \\
\hline hatched zone and diagonal lines & 0.7 & - \\
\hline curvilinear/circular lines & 12.7 & - \\
\hline $\mathrm{N}$ & 134 & 4 \\
\hline
\end{tabular}

*percentage (do not total to $100 \%$ because non-diagnostic elements [i.e., single straight lines] are not included in the tabulation); ** sandy paste

Table 10. Engraved bottle sherd decorative elements from the Boyette site.

\begin{tabular}{lcc}
\hline Element & Block I & Block II \\
\hline Hickory Engraved & $23.5^{*}$ & - \\
Holly Fine Engraved & 5.9 & 71.4 \\
semi-circles & 11.8 & - \\
panel and negative ovals & 5.9 & - \\
parallel lines & - & 14.3 \\
curvilinear-horizontal lines & - & 14.3 \\
curvilinear & 52.9 & - \\
\hline $\mathrm{N}$ & $17^{* *}$ & 7 \\
\hline$\%$ of all engraved body sherds & 9.5 & 58.3 \\
\hline
\end{tabular}

*percentage; **includes three Hickory Engraved rims 


\section{Utility Wares at Boyette}

Among the incised utility wares, the decorative elements that differentiate the Early Caddo from later Caddo ceramic assemblages are the more common use of cross-hatching (including cross-hatched and horizontal sets of lines), diagonal incising on vessel bodies, and the occurrence of various Dunkin Incised motifs (Table 11) on both rim and body sherds (Figure 9d, h and Figure 10b). Cross-hatched rims comprise between $16.7-32.1 \%$ of the rims from both blocks at the Boyette site, and 2.3-2.4\% of the incised body sherds have diagonal incised lines. In later Caddo ceramic assemblages at Lake Naconiche, only $3.7-6.7 \%$ of the incised rims are cross-hatched; diagonal incised rims are much more common (Perttula 2008:Table 7-10).

The punctated rim and body sherds at the Boyette site are characterized primarily by a wide variety of decorative elements (Table 12), among them being the ubiquitous tool punctated row element. However, the most distinctive punctated elements in the Early Caddo ceramics compared with later punctated utility wares is the more common use of rows of fingernail ( $40 \%$ of the punctated sherds, but less than $20 \%$ at each of the other Lake Naconiche sites), linear, and circular and small circular punctations as decorative elements (Table 13). Another distinctive punctated decorative element is the use of free or randomly spaced tool punctates on the vessel body.

In the case of the incised-punctated decorative elements, the Early ceramic set includes as diagnostic Weches Fingernail Impressed, var. Weches (see Figure 9b and Figure 10a), incised triangles filled with tool punctations, and in Block II at Boyette, rims with horizontal incised lines above rows of tool punctates; the latter two incised-punctated decorative elements are also present in later Lake Naconiche assemblages (Table 14). In Block I, there also are a considerable proportion of rims with curvilinear or circular incised zones filled with linear or tool punctates (see Figure 9c, e), sometimes occurring in association with diagonal incised lines

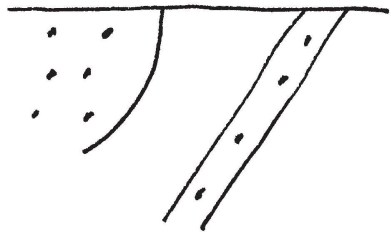

a

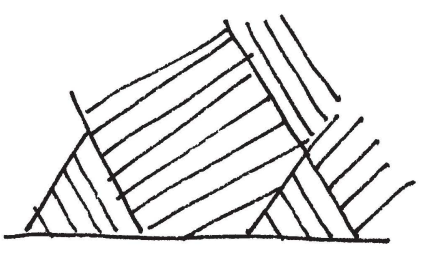

d

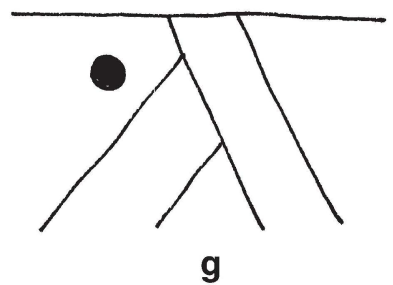

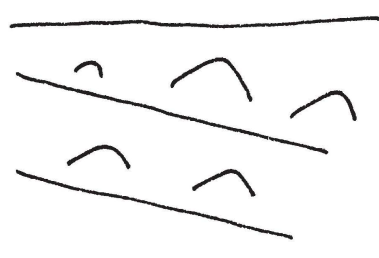

b

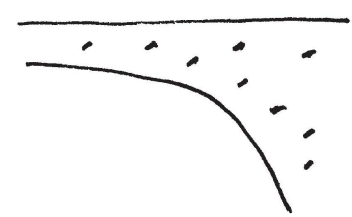

e

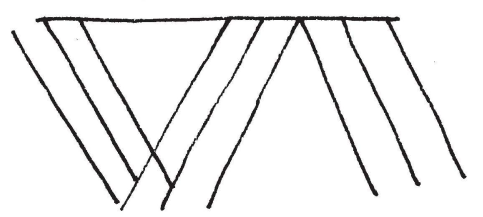

$\mathbf{h}$

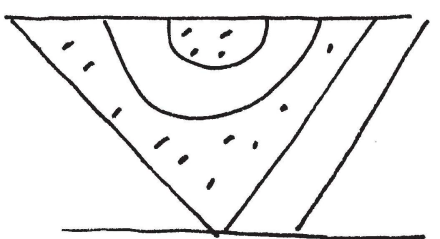

C

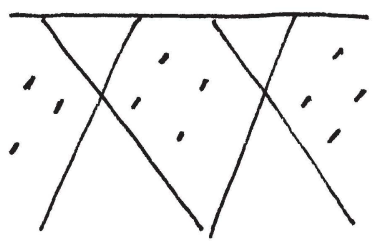

f

Figure 9. Distinctive utility ware decorative elements in Block I: a, c, e-f, incised-punctated; b, Weches Fingernail Impressed, var. Weches; d, Dunkin Incised; g-h, incised lines; g has a suspension hole below the vessel lip. 


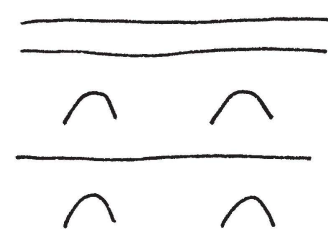

a

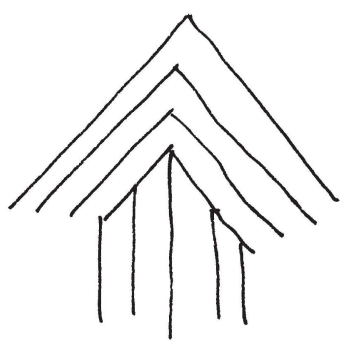

b
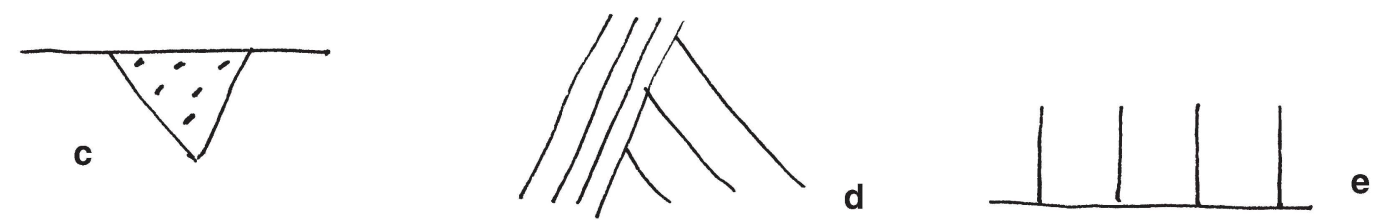

Figure 10. Block II distinctive utility ware decorative elements: a, Weches Fingernail Impressed, var. Weches; b, Dunkin Incised; c, incised-punctated; d, diagonal opposed incised lines; e, horizontal and vertical incised lines.

Table 11. Incised decorative elements by block.

\begin{tabular}{lcc}
\hline Element & Block I & Block II \\
\hline Rim & $26.4^{*}$ & \\
diagonal & 11.3 & 16.7 \\
horizontal & 3.8 & 50.0 \\
horizontal-diagonal & 11.3 & - \\
opposed & 32.1 & - \\
cross-hatched & - & 16.7 \\
vertical & 9.4 & 8.3 \\
curvilinear & 3.8 & 8.3 \\
diagonal-curvilinear & 3.8 & - \\
Dunkin Incised & 53 & - \\
N & & 12 \\
& & \\
Body & 37.0 & 62.8 \\
parallel & - & 2.3 \\
horizontal and vertical & 9.7 & 14.0 \\
opposed & 1.2 & - \\
opposed-diagonal & 18.2 & - \\
cross-hatched & 1.2 & - \\
cross-hatched-horizontal & 2.4 & 2.3 \\
diagonal & 0.6 & - \\
vertical & 9.1 & 2.3 \\
curvilinear-semi-circle & 0.6 & 2.3 \\
Dunkin Incised & 165 & 43 \\
N & & \\
\hline
\end{tabular}

*percentage 
Table 12. Punctated decorative elements in the Boyette sherds.

\begin{tabular}{lcc}
\hline Element & Block I & Block II \\
\hline tool punctated row & $23^{*}$ & 42 \\
tool punctates & 5 & - \\
tool punctates, free & 1 & - \\
small tool punctates, free & 11 & - \\
tool punctates under lip & - & 2 \\
diagonal tool punctated row & 0.7 & 2 \\
tool-fingernail punctates & 0.7 & - \\
small cane punctate row & 0.7 & 40 \\
fingernail punctated row & 29 & - \\
fingernail punctates & 11 & - \\
diagonal fingernail punctated row & 1.3 & - \\
curvilinear punctate, cf. Weches & 0.7 & 11 \\
linear punctates & 5 & - \\
circular punctates & 3 & - \\
small circular punctates & 5 & 52 \\
\hline $\mathrm{N}$ & 149 & \\
\hline
\end{tabular}

*percentage

Table 13. The prevalence of punctated decorative elements by period.

\begin{tabular}{lccc}
\hline Element & Early Caddo & Middle-Late Caddo* & Late Caddo \\
\hline fingernail punctated row & $\mathrm{X}$ & & \\
linear punctated & $\mathrm{X}$ & & \\
small circular punctated row & $\mathrm{X}$ & & \\
small tool punctates, free & $\mathrm{X}$ & $\mathrm{X}$ & \\
tool punctated row & & $\mathrm{X}$ & $\mathrm{X}$ \\
cane punctated row & & $\mathrm{X}$ & \\
Naconiche Punctated & & & \\
tool punctates under lip & & & \\
\hline
\end{tabular}

*includes 41NA231, 41NA235, and 41NA242 (all apparently abandoned by ca. A.D. 1450)

and semi-circles filled with punctations (see Figure 9a); these resemble designs seen on Crockett Curvilinear Incised vessels. One Early Caddo rim has cross-hatched incised lines forming diamonds filled with punctations (see Figure 9f).

The incised-punctated body sherds in the Early Caddo ceramic assemblages from the Boyette site share one decorative stylistic tendency: the use of circular or curvilinear incised zones filled with punctates (Table 15): between 28.6-49\% of the body sherds from the Boyette site blocks have this distinctive decorative element on utility wares. Both blocks at the Boyette site also have many triangular incised sherds filled with punctates: in the case of Block I, most of them are filled with tool punctates (as is also the case with the later Lake Naconiche incised-punctated ceramic assemblages), while fingernail punctates and cane punctates were more often employed to fill these incised zones in the Block II ceramics.

Incised-punctated sherds with incised lines either above or below rows of tool or fingernail punctates are particularly common in Block II at the Boyette site. As with the decorated rims, Weches 
Table 14. Incised-Punctated rim decorative elements by block.

\begin{tabular}{lcc}
\hline Element & Block I & Block II \\
\hline $\begin{array}{l}\text { Weches Fingernail Impressed } \\
\text { diagonal incised next to tool, }\end{array}$ & $18.2 *$ & 20.0 \\
$\begin{array}{l}\text { linear, or circular punctates } \\
\text { circular or curvilinear incised }\end{array}$ & 18.2 & - \\
$\begin{array}{l}\text { zones filled with tool punctates } \\
\text { curvilinear incised zones filled } \\
\text { with linear punctates }\end{array}$ & 18.2 & - \\
$\begin{array}{l}\text { cross-hatched incised with } \\
\text { circular punctates }\end{array}$ & 4.5 & - \\
$\begin{array}{l}\text { vertical incised with tool } \\
\text { punctated zones }\end{array}$ & 4.5 & - \\
$\begin{array}{l}\text { incised panel-fingernail punctates } \\
\text { circular-diagonal incised and } \\
\text { tool punctates } \\
\text { semi-circular and incised triangles } \\
\text { filled with tool punctates }\end{array}$ & 4.5 & - \\
incised triangles filled with \\
tool punctates \\
horizontal incised and rows of \\
tool punctates
\end{tabular}

Table 15. Incised-Punctated body decorative elements.

\begin{tabular}{lcc}
\hline Element & Block I & Block II \\
\hline circular or curvilinear incised zones filled with punctates & $49 *$ & 28.6 \\
triangular incised zones filled with tool punctates & 39 & - \\
triangular incised zones filled with circular punctates & 2.8 & - \\
triangular incised zones filled with fingernail punctates & 1.4 & 14.3 \\
triangular incised zones filled with cane punctates & - & 14.3 \\
incised elements with tool punctated rows & 2.8 & 14.3 \\
incised elements with fingernail punctated rows & - & 28.6 \\
Weches Fingernail Impressed & 4.2 & - \\
\hline $\mathrm{N}$ & 72 & 7 \\
\hline *percentage & &
\end{tabular}


Fingernail Impressed, var. Weches sherds are present in the incised-punctated body sherds characteristic of the Early ceramic set.

\section{CONCLUSIONS}

The Early Caddo occupations at the Boyette site (41NA285) appear to be contemporaneous with the earliest Alto phase component at the George C. Davis site on the Neches River, dating as the latter does from the mid- $9^{\text {th }}$ century A.D. However, the fine wares and the utility wares found there do not suggest that the Boyette site is a component of the Alto phase, although such sites have been identified in the Angelina River basin (see Story 2000:Figure $5)$. Story $(2000: 20)$ has previously pointed out that "components of this phase are no where common even though some of the diagnostics, such as Weches Fingernail Punctated and Holly Fine Engraved, have wide distributions." Such appears to be the case here, because while there are a few sherds of Holly Fine Engraved and Weches Fingernail Impressed in the Boyette site decorated sherds, they do not dominate the decorated sherd assemblages - along with Davis Incised, Dunkin Incised, Crockett Curvilinear Incised, Pennington Punctated-Incised, Hickory Engraved, and Duren Neck Banded-as they do as the George C. Davis site (Stokes and Woodring 1981:Table 24). For example, Stokes and Woodring (1981:Table 24) note that Holly Fine Engraved vessel sherds and Weches Fingernail Punctated sherds comprise both between $16-41 \%$ of the more than 14,000 decorated sherds from mound and domestic contexts across the site, and incised-punctated Crockett Curvilinear Incised and Pennington Punctated Incised sherds are also fairly well-represented (2-19\% by excavation areas) at this mound center. Only a handful of sherds from the Boyette site were identified as coming from either Holly Fine Engraved or Weches Fingernail Impressed/Punctated vessels. Less than $13 \%$ of the sherds at the Boyette site have incised-punctated decorative elements, although between $30-50 \%$ of these have curvilinear zoned incised and punctated elements, few of which remotely resemble in execution Crockett Curvilinear Incised vessels. At best, then, the few similarities in vessel decorations in both fine wares and utility wares between the Boyette site and the well-known George C. Davis site are indicative of contemporaneous Caddo occupations - and perhaps even a modicum of contact/interaction - but they do not belong to the same Caddo groups. Instead, the Boyette site is apparently a component of a local and culturally separate Caddo community in the upper Angelina river basin, one that is currently taxonomically unidentified.

One question that languishes unanswered is the cultural relationship between the latest Mossy Grove sites in East Texas and the earliest Caddo sites in the region. Concerning the historical traditions of the Alto phase Caddo peoples that lived in this general area, Story $(2000: 25)$ has commented that "there are no earlier archeological remains in the middle and upper Neches River basin that can plausibly be identified as an antecedent complex to the Alto phase component [at the George C. Davis site]." She goes on to speculate that "earlier Caddoan developments [earlier than the late A.D. $800 \mathrm{~s}$ ] must have taken place elsewhere, probably to the northeast in either the Sabine or Red River basins." These suggestions go hand in hand with the notion that the George C. Davis Caddo mound center represents a founding colony in a part of East Texas that was not previously within the territory occupied by Caddo peoples.

Corbin (1989:121) also subscribes to the notion that the Caddo occupation of East Texas, or at least those areas south and west of the Sabine River, originates outside of East Texas and that the Caddo were newcomers to the region. He also proposed that the Caddo populations who had come into the area in the A.D. 800s lived coevally with the East Texas Woodland peoples (i.e., the Mossy Grove Culture peoples) who were already there, and that these Woodland peoples continued "their dispersed lifestyle, only slightly displaced on the landscape, with the additions of maize, better pottery and the bow and arrow." Under this scenario, the:

\section{indigenous Woodland population was ac- culturating and modifying some of what was early Caddo culture into their own lifestyle to create a post-early Caddoan culture we call Late Caddo on a cultural base that was already in place and never disappeared. The only place where early Caddo blinked into almost instantaneous existence in this area was at a few specific sites (Corbin 1989:124).}

Probably the only means to fully evaluate the relationships between, and cultural affiliations of, the Mossy Grove Woodland period groups and the earliest Caddo archaeological sites will be exten- 
sive bioarchaeological and genetic studies of DNA, oxygen/strontium isotopes, and genetic markers preserved on human skeletal remains, as these provide the highest probability of establishing cultural and biological relationships between various groups of people recognized in the archaeological record. It is doubtful, however, that this can ever be fully achieved because to date not a single Woodland period burial has ever been found in a domestic site in East Texas, and $9^{\text {th }}$ century Caddo sites are almost as rare, whether with burials or not. Furthermore, it is an open question whether DNA or traces of genetic markers left on human skeletal remains are even preserved in any such sites occupied on the cusp of the Woodland to earliest Caddo time periods.

That being said, the prehistoric occupations at the Boyette site are nevertheless relevant to the questions and scenarios posed by Story (2000) and Corbin (1989). From radiocarbon dates obtained in the excavations here, as discussed above, there are two occupations of interest, one that dates (with a 95\% probability) from cal A.D. 667-847 (with a mean calibrated intercept from three dates of $\mathrm{AD}$ 743 ) and the other that dates (with a 95\% probability) between cal $\mathrm{AD} 873-1075$, with a mean calibrated intercept (from four dates) of $\mathrm{AD} 960$. Two of the four dates have a mean calibrated age range of AD 750-990 (calibrated intercepts of AD 880 and 900), while the other two have a mean calibrated age range of $\mathrm{AD}$ 995-1160 (calibrated intercepts of $\mathrm{AD}$ 1020 and 1040). These radiocarbon ages suggest that the second occupation may be represented by two different episodes of settlement.

The earlier of the two occupations (identified in the deepest archaeological deposits in Blocks I and II) has sandy paste Goose Creek Plain and decorated Mossy Grove ceramics, Gary and Kent dart points (and probably some early arrow point forms), a few features, but no evidence of structures, middens, burials, or use of cultigens. In most respects, this early occupation at the Boyette is a fairly typical Mossy Grove period occupation. There is one (to some) troubling aspect in the material culture of this component: decorated sandy paste vessel sherds are apparently atypically abundant (more so than any other known Mossy Grove component, unless all of them have moved by bioturbation from overlying Caddo archaeological deposits, which is unlikely), and the incised, incised-punctated, and incised decorative elements almost eerily presage the same ceramic vessel decorations noted in the later ca. $\mathrm{AD}$ 985 component. In the latter occupation, these styles of vessel decoration are common on both sandy paste and tempered pottery wares. There are at least a few examples of non-traditional vessel forms in the ca. AD 743 component, including carinated bowls and a bottle. Such vessel forms are well represented in the later ca. AD 985 component, as they are in post-A.D. 1100 Naconiche Caddo ceramic vessel assemblages.

What about the ca. AD 985 component: is it affiliated with the Caddo or is it an acculturated Mossy Grove site? First, it can be noted that cultigens are absent in the archaeological deposits associated with this occupation, although the numbers and arrangements of features suggest that this occupation was a relatively sedentary one as there is evidence of sequential central hearths from two different houses that date to the earlier of the two later occupational episodes (i.e., ca. A.D. 750-990 from radiocarbon, but centering around A.D. 880-900). There are stemmed arrow points in the assemblage, including those of the Alba type (the dominant type in the Alto phase) and an abundance of ceramic vessel sherds, including many from carinated bowls and bottles that have engraved designs (i.e., Holly Fine Engraved and Hickory Engraved) much like those noted from other early Caddo contexts in the region. Much of the pottery is tempered-primarily with grog - but sandy paste pottery remains an important part of the ceramic vessel assemblage in this later component. More importantly, the sandy paste pottery in this late $9^{\text {th }}$-early $10^{\text {th }}$ century occupation is commonly decorated with the same decorative elements common in the tempered wares, even including some amount of engraved sandy paste pottery.

From the evidence at hand from the Boyette site at Lake Naconiche, it appears that there were changes in material culture - the use of temper in the manufacture of pottery vessels, subtle changes in vessel form, and innovations in pottery vessel decoration - that were either underway by the mid- $8^{\text {th }}$ century and/or had been adopted by the aboriginal peoples living along Naconiche Creek by the late $9^{\text {th }}$ century, a period of some 150 years (or at least six generations). The choice and inspiration to decorate sandy paste pottery cannot be laid at the feet of any Caddo colonizers from the George C. Davis site or others of its ilk because this was taking place at least one century before the appearance of that site on the Neches River. The same may be said for the appearance of carinated bowl and bottle forms in late Mossy Grove contexts at the Boyette site. Such innovations as these appear to have devel- 
oped amongst Mossy Grove groups without having to invoke a Caddo "influence," if that is relevant in the context posed by Story (2000) and Corbin (1989). Perhaps it is plausible that further ceramic innovations such as adding temper to the paste of vessels, or even choosing to decorate a vessel after it was fired rather than while the vessel still had a wet paste, were not beyond the creative reach of the people that lived along Naconiche Creek or in other areas of East Texas.

Thus, in the end, and based on admittedly very sketchy archaeological information, I do not view the $9^{\text {th }}$ century occupation at the Boyette site as acculturated Mossy Grove groups influenced by the superior culture of the Caddo who were expanding into the area. Rather, I view the $7^{\text {th }}$ and $8^{\text {th }}$ century population at Lake Naconiche as directly antecedent to the $9^{\text {th }}$ century population that lived at the Boyette site. In most particulars, the preponderance of archaeological evidence from this later occupation indicates that the population that lived there was Caddo, or at least one of many different groups living in East Texas that can be considered Caddo in an ethnic sense. The $7^{\text {th }}$ and $8^{\text {th }}$ century A.D. Woodland population is considered ancestral to the Caddo. This does not mean that the Woodland or earliest Caddo populations in the Attoyac Bayou basin had any ethnic or underlying genetic relationship with the founding population at George C. Davis - that issue still remains to be teased out. It does mean that the George C. Davis Caddo population was not the only one in East Texas in the $9^{\text {th }}$ century A.D.

\section{REFERENCES CITED}

Brown, I. W.

1998 Decorated Pottery of the Lower Mississippi Valley: A Sorting Manual. Mississippi Archaeological Association and Mississippi Department of Archives and History, Jackson.

Corbin, J. E.

1989 The Woodland/Caddo Transition in the Southern Caddo Area. In In the Light of Past Experience: Papers in Honor of Jack T. Hughes, compiled and edited by B. C. Roper, pp. 117-124. Publication No. 5. Panhandle Archeological Society, Clarendon.
1998 Reflections on the Early Ceramic Period and the Terminal Archaic in South Central East Texas. Journal of Northeast Texas Archaeology 11:108-116.

Perttula, T. K. (editor)

2002 Archeological Investigations at the Proposed Lake Naconiche, Nacogdoches County, Texas. 2 Vols. Report of Investigations No. 42. Archeological and Environmental Consultants, Austin.

2008 Lake Naconiche Archeology, Nacogdoches County, Texas: Results of the Data Recovery Excavations at Five Prehistoric Archeological Sites. 2 Vols. Report of Investigations No. 60. Archeological \& Environmental Consultants, LLC, Austin.

Perttula, T. K. and B. Nelson

2004 Woodland and Caddo Archeology at the Broadway or Kanduts'ah Kuhnihdahahdisa' Site (41SM273) on the City of Tyler-Lake Palestine WTP Project, Smith County, Texas. Report of Investigations No. 50. Archeological \& Environmental Consultants, LLC, Austin.

Stokes, J. and J. Woodring

1981 Native-Made Artifacts of Clay. In Archeological Investigations at the George C. Davis Site, Cherokee County, Texas: Summers of 1979 and 1980, edited by D. A. Story, pp. 135-238. Occasional Papers No. 1. Texas Archeological Research Laboratory, The University of Texas at Austin.

Story, D. A.

1990 Cultural History of the Native Americans. In The Archeology and Bioarcheology of the Gulf Coastal Plain, by D. A. Story, J. A. Guy, B. A. Burnett, M. D. Freeman, J. C. Rose, D. G. Steele, B. W. Olive, and K. J. Reinhard, pp. 163-366. 2 Vols. Research Series No. 38. Arkansas Archeological Survey, Fayetteville.

2000 Introduction. In The George C. Davis Site, Cherokee County, Texas, by H. P. Newell and A. D. Krieger, pp. 1-31. Second edition. Society for American Archaeology, Washington, D.C.

Story, D. A. (editor)

1995 The Deshazo Site, Nacogdoches County, Texas, Volume 2: Artifacts of Native Manufacture. Studies in Archeology 21. Texas Archeological Research Laboratory, The University of Texas at Austin. 